\title{
HOUSEHOLD ENVIRONMENT FACTORS ASSOCIATED WITH ACUTE RESPIRATORY INFECTION (ARI) AMONG UNDER-FIVE CHILDREN
}

\author{
Nurul Hidayah ${ }^{1 *}$ \\ ${ }^{1}$ Sari Mulia School of Health Science, Banjarmasin, Indonesia \\ *nurulhidayah@stikessarimulia.ac.id \\ R. Topan Aditya Rahman ${ }^{2}$ \\ ${ }^{2}$ Sari Mulia Midwifery Academy Banjarmasin, Indonesia \\ r_topan_aditya@akbidsarimulia.ac.id \\ Desilestia Dwi Salmarini $^{2}$ \\ ${ }^{2}$ Sari Mulia Midwifery Academy Banjarmasin, Indonesia \\ r_topan_aditya@akbidsarimulia.ac.id
}

\begin{abstract}
Objective: The purpose of this study was to find out the association of house environment with Acute Respiratory Infection (ARI) incidence in Pudi Village, North Kelumpang District, Kotabaru Regency.

Method: This research was using a survey method with analytic cross-sectional study design. The Instrument was using observation list. Sample size about 90 houses and underfive children in Pudi village. They were taken by total sampling. The data were analyzed using Chi-square test.

Results: Under-five children who experienced ARI about 35 people (38.9\%). Ventilation conditions which not qualify about 74 houses $(82.2 \%)$ and residential density which not qualify about 60 houses (66.7\%). Statistical test results obtained p-value $=0.001$ for the association of ventilation conditions with ARI and p-value $=0.000$ for association of residential density with ARI.
\end{abstract}

Conclusion: The ventilation conditions and residential density significantly related to the incidence of ARI.

Keywords: Acute Respiratory Infection (ARI), Environment, Residential Density, Ventilation

\section{INTRODUCTION}

Acute Respiratory Infection (ARI)

is one of the major tropical diseases that are the leading cause of infectious morbidity and mortality in the world in infants and children, especially in countries with low and middle income per capita [1]. According to the World Health Organization (WHO) report, ARI is the leading cause of death in infants in the world with Proportional Mortality Rate (PMR) in children under five years $17 \%$ per 1000 live births [1]. 
ARI is still a problem in Indonesia. This is evident from the results of basic research (Riskesdas) in Indonesia in 2013 shows the prevalence of ARI in infants $35.92 \%$ per 1000 live births and toddlers $42.53 \%$ per 1000 children under five. Episodes of ARI disease in infants in Indonesia are estimated to be 3-6 times per year, which means an average child suffering from ARI as much as 3 to 6 times a year [2].

ARI is one cause of death for infants and toddlers in Indonesia. Most of these deaths are caused by a lower respiratory infection (pneumonia). Reports of 10 most diseases in hospitalized patients in hospitals in Indonesia in 2012 showed pneumonia disease has the highest CFR, $6.63 \%$ of 1000 infants. The PMR rate due to pneumonia in infants in Indonesia is $22 \%$ per 1000 live births [2].

ARI is also one of the main causes of patient visits in health facilities that is as much as $40 \%-60 \%$ visit treatment at community health centers and 15\% $-30 \%$ of outpatient visits in outpatient and inpatient hospitals. In South Kalimantan, the incidence of ARI is 4955 cases in 2012 and 5479 cases in 2013. This indicates an increase of $9.5 \%$ [3].

Kotabaru regency is one of the regencies in South Kalimantan Province. Pudi public health center is a health center in North Kelumpang district, Kotabaru where ARI is still a problem in the area. This can be seen from the incidence of ARI in infants in 2012 is 235 cases of 405 toddlers $(58 \%)$ and the year 2013 is 170 cases of 525 toddlers (32.4\%). However, seen from the top 10 diseases that ranked first is the ARI for the last 2 years in a row that is in 2012 and 2013. In addition, in 2012 there are 2 children under five pneumonia and 1 of whom should be referred. While in 2013 there is 1 child under five who died of the disease [4].

The village closest to Pudi Public Health Center is Pudi Village, so many people in the village come to visit it. The number of children affected by ARI in Pudi Village in the last 2 years also increased, in 2012 there were 58 people among 110 infants (52.7\%) and in 2013 there were 69 people among 125 under five $(55.2 \%)$. In addition, the population is the largest of 7 villages in the working area of Pudi Public Health Center [4].

The results of interviews and simple observations to the mother of children under five in Pudi Village in March 2014 found that from 10 children under five who had ARI, 8 people (80\%) lived in an unqualified home environment. Among these 8 persons, 3 people $(37.5 \%)$ did not have adequate home ventilation of less than $10 \%$ of floor area, 2 people $(25 \%)$ lived in large families, 2 heads of households in one house, 3 people 
(37.5\%) live in a home environment with unsuitable ventilation and dwelling conditions.

The results of Rosalina [5] showed that there was a significant correlation between determinant factors such as lack of nutritional status, exclusive breastfeeding, low birth weight, cigarette smoke pollution and kitchen smoke, immunization status incomplete with ARI occurrence. the incidence of ARI is suspected to be more severe when accompanied by environmental conditions that are not eligible home.

Most of the economic conditions of the people in Pudi Village are the middle to lower class, thus causing the community not to pay much attention to the condition of their home environment, such as a very simple house with poor ventilation or air circulation and a large number of family members living in one house. This resulted in increased risk of ARI disease spread in the village.

Based on the above things can be seen that the current ARI disease is still a health problem that needs attention and needs to be addressed immediately. ARI is a disease that one of the causes is the environmental condition of the house. Source of pollution in the house, among others, combustion of fuel used for cooking and cigarette smoke. In addition, other causes are spatial arrangements include ventilation, density, the location of the kitchen, and others.

A previous study conducted by Rumaolat [6], who stated that there is significant relationship between ventilation and ARI incident on children under five years who live in a residential home due to the disaster of Merapi cold lava in Salam sub district. Toddlers who stay at home with ventilation that does not qualify will be more likely to be exposed to health problems such as ARI [7]. This is due to air exchange which does not qualify then it can make the fertile growth of microorganisms that cause health problems of humans [8].

Residential density is also suspected to affect the occurrence of ARI in infants. Toddlers who stay home with not eligible residential density 2.71 times higher risk of developing ARI compared to toddlers who living in homes with eligible residential density [9]. The study of Farieda [10] shown that toddlers who stay home with not eligible residential density 10.75 times greater risk of respiratory infection compared with toddlers exposed to living in a house with eligible residential density.

For that we need to do research about the relationship of environmental conditions of the house with the incidence of ARI in Pudi Village, North Kelumpang District, Kotabaru Regency. 
II. METHOD

\section{Study Design}

This research is an analytic survey research with cross sectional study approach.

\section{Sample Size and Sampling Technique}

The population in this study were all children under five in Pudi Village, Kelumpang Utara Subdistrict, Kotabaru in July 2014, which amounted to 90 children under five. The sample of the study was taken with total sampling technique or whole population taken as research sample that is as much 90 people.

\section{Data Collection}

Measurements of variables of ventilation conditions, density and incidence of ARI were done using observation method.

\section{Statistical Analysis}

Data were analyzed using chi-square test $\left(X^{2}\right)$ to know the relation of ventilation condition and occupancy density with the

incidence of ARI on significance level $\alpha=$ 0,05 .

\section{RESULTS}

The results of data collection obtained most respondents in this study female sex were 51 people $(56.7 \%)$. Respondents of male sex were 39 people (43.3\%). By age, it known that the majority of respondents in this study aged 13-60 months was 72 people (80\%). Respondents aged 1-12 months were 18 people (20\%) (Figure 1 and 2).

Sex

$$
\begin{aligned}
& 80 \% \\
& 60 \% \\
& 40 \% \\
& 20 \%
\end{aligned}
$$

$0 \%$

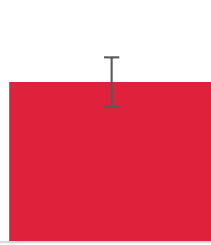

Male

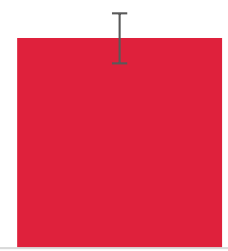

Female

Figure 1. Respondent characteristic based on sex 


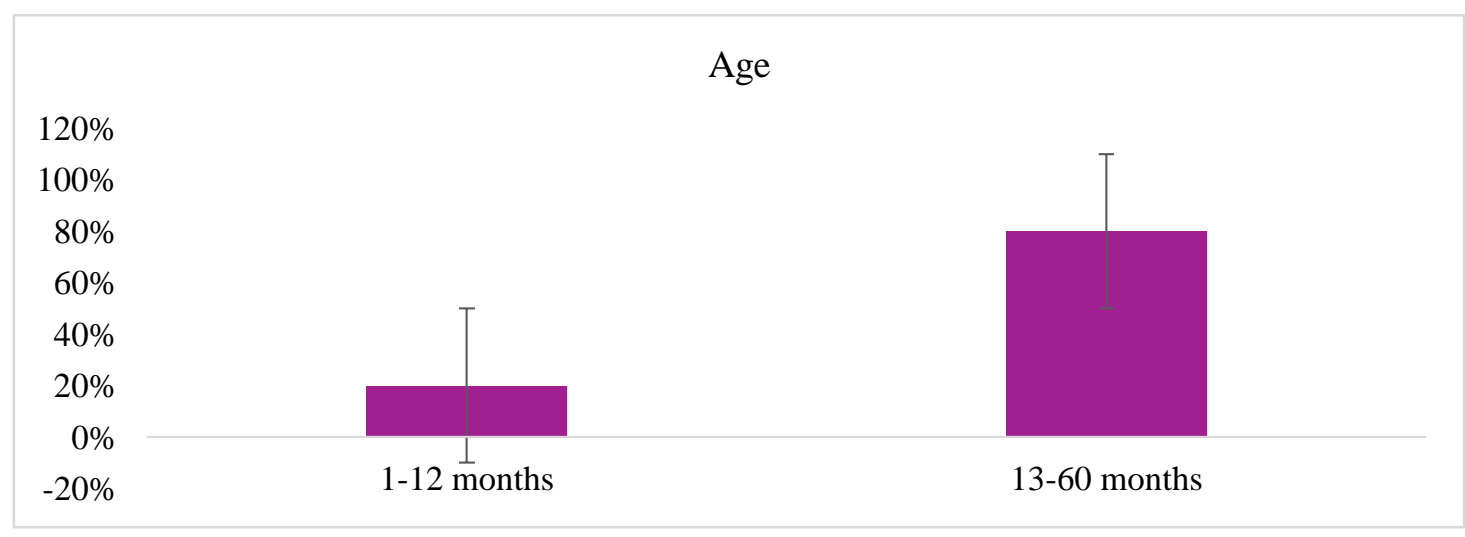

Figure 2. Respondent characteristic based on age

The environmental conditions of the stayed at home with unsuitable occupancy house under study include ventilation density conditions and most respondents conditions and occupancy density. The did not experience Acute Respiratory data obtained are presented along with ARI (tabel 1). Infections $(61.1 \%)$.

Based on table 1 it is found that most Cross tabulation between home of the respondents staying at home with unsuitable ventilation condition 74 people environmental conditions and Acute Respiratory Infections events can be seen in tables 2 and 3.

$(82.2 \%)$. In addition, 60 people $(66.7 \%)$

Table 1. The Univariate analysis of ventilation condition, residential density and Acute Respiratory Infections

\begin{tabular}{lcc}
\multicolumn{1}{c}{ Variable } & frequency & $\%$ \\
\hline Ventilation condition & & \\
$\quad$ Not Qualify & 74 & 82.2 \\
Qualify & 16 & 17.8 \\
Residential density & & 66.7 \\
$\quad$ Not Qualify & 60 & 33.3 \\
$\quad$ Qualify & 30 & 38.9 \\
Acute Respiratory Infections & & 61.1 \\
$\quad$ Yes & 35 & \\
Not & 55 & \\
\hline
\end{tabular}

Table 2. Cross-tabulation of ventilation condition and Acute Respiratory Infections

\begin{tabular}{|c|c|c|c|c|c|c|}
\hline \multirow{3}{*}{ Ventilation condition } & \multicolumn{4}{|c|}{$\begin{array}{l}\text { Acute Respiratory } \\
\text { Infections }\end{array}$} & \multirow{3}{*}{ Total } & \multirow{3}{*}{$\%$} \\
\hline & \multicolumn{2}{|c|}{ Yes } & \multicolumn{2}{|c|}{ No } & & \\
\hline & $\mathrm{n}$ & $\%$ & $\mathrm{n}$ & $\%$ & & \\
\hline Not Qualify & 35 & 47.5 & 39 & 52.7 & 74 & 100 \\
\hline Qualify & 0 & 0 & 16 & 100 & 16 & 100 \\
\hline Total & 35 & 38.9 & 55 & 61.1 & 90 & 100 \\
\hline
\end{tabular}


Table 3. Cross-tabulation of Residential density and Acute Respiratory Infections

\begin{tabular}{|c|c|c|c|c|c|c|}
\hline \multirow{3}{*}{ Residential density } & \multicolumn{4}{|c|}{ Acute Respiratory Infections } & \multirow{3}{*}{ Total } & \multirow{3}{*}{$\%$} \\
\hline & \multicolumn{2}{|c|}{ Yes } & \multicolumn{2}{|c|}{ No } & & \\
\hline & $\mathrm{n}$ & $\%$ & $\mathrm{~N}$ & $\%$ & & \\
\hline Not Qualify & 35 & 58.3 & 25 & 41.7 & 60 & 100 \\
\hline Qualify & 0 & 0 & 30 & 100 & 30 & 100 \\
\hline Total & 35 & 38.9 & 55 & 61.1 & 90 & 100 \\
\hline
\end{tabular}

The results obtained that from 74 respondents living in the home environment with unsuitable ventilation conditions there were 39 people $(52.7 \%)$ who did not have ARI. Of the 16 respondents living in the home environment with eligible ventilation conditions, all (100\%) had no ARI (table 2).

In table 3, it is known among 60 respondents who live in the house environment with unsuitable occupancy density, there were 35 people $(58.3 \%)$ who had ARI. Among the 30 respondents living in the home environment with eligible dwelling density, all (100\%) had no ARI.

The results of statistical tests show that there is a significant relationship between the condition of room ventilation and density of occupancy with the incidence of ARI in under five children (table 4).

Table 4. Association of ventilation condition and residential density with Acute Respiratory Infections

\begin{tabular}{lcc}
\hline \multicolumn{1}{c}{ Variable } & p-value & Remark \\
\hline Ventilation condition & 0.001 & Correlated \\
Residential density & 0.000 & Correlated \\
\hline
\end{tabular}

\section{DISCUSSION}

Ventilation Condition Associated with Acute Respiratory Infections

This study has proved the relationship between ventilation condition and the occurrence of Acute Respiratory Infections $(p$-value $=0.001)$. This indicates that toddlers living in homes with inadequate ventilation conditions may be exposed to ARI.

Ventilation is useful for the provision of fresh air into and expenditure of air from enclosed spaces. Lack of ventilation will cause the lack of oxygen and fresh air in the house, causing the increase of air humidity, otherwise it can cause accumulation of pollutants inside the house, especially in the bedroom making it easier for the occurrence of disease transmission, especially respiratory disorders [11].

Toddlers living in the home environment with inadequate ventilation conditions will be more susceptible to ARI, while toddlers who live in the home environment with eligible room ventilation have a lower risk of ARI disease. 
This is because with sufficient ventilation will allow smooth air circulation in the room and the entry of sunlight that can kill bacteria. Ventilation is quite useful to avoid the adverse effects that can harm human health. With good ventilation will occur wind movement and clean air exchange smoothly.

The results of this study are in line with the results of M. Nur's study [12], where there is a significant relationship between ventilation conditions and the incidence of ARI disease where in general, ARI disease occurs in infants from ventilated households who do not meet health requirements. Ventilation is useful for providing fresh air into and discharge of dirty air from enclosed spaces. Lack of ventilation causes a lack of air circulation clean and fresh indoors, otherwise it will cause the increase of air humidity.

\section{Residential Density Associated with Acute Respiratory Infections}

This study proves the relationship between residential density and the occurrence of Acute Respiratory Infections ( $\mathrm{p}$-value $=0.000)$. According to Lubis [13], the condition of the full room feels quite hot and humid, due to the moisture generated from the evaporation of the body's metabolism. In relation to disease occurrence, occupancy density may cause cross-infectious, where if there is an ARI sufferer in a crowded room it will rapidly pass it on to others by air or droplet, where the cough of the disease agent comes out in droplet form and will be dispersed into the air and then in to the new host body through the respiratory tract.

Toddlers living in houses with density of ineligible dwelling will be more susceptible to ARI disease, whereas toddlers living in houses with density of eligible dwelling have a lower risk of ARI disease.

The results of this study are in line with the results of Taisir [14], where from 213 infants with ARI were $39 \%$ and bivariate analysis showed that there was a significant relationship between occupancy density and ARI occurrence. This study was supported by Prietsch's research, at al [15], indicating a significant relationship between the density of the house (persons/bedroom) and the incidence of ARI ( $p$-value $=0.001$ ).

In addition, the study of Fakunle [16], obtained children whose homes had more than two persons per room were found to have a 14-fold greater risk of ARI than children in houses with fewer than two persons per room. Research by Padmita [17] shows that environment factor which is associated with ARI among children under five years was a residential density of house $(\mathrm{OR}=3.39)$. 
Density in the room especially the toddler room that does not comply with the standard will cause the room crowded so that oxygen decreases and $\mathrm{CO} 2$ increases in the room. This is because the building area is not proportional to the number of occupants is not healthy and can lead to lack of oxygen consumption and facilitate the transmission of infectious diseases. The density of the dwelling can affect the quality of air inside the house, where the more the number of occupants the faster the air inside the house will be polluted.

\section{CONCLUSION}

There was a significant association between the condition of room ventilation and occupancy density with the incidence of ARI among under five children.

\section{REFERENCES}

1. WHO. Global Health Risk. Mortality and Burden of Disease Attributable to Selected Major Risks. Geneva. (http://www.who.int/). 2013.

2. Departemen Kesehatan RI. Pedoman Pemberantasan Penyakit Infeksi Saluran Pernafasan Akut untuk Penanggulangan Pneumonia pada Balita dalam Pelita VI. Jakarta: Dirjen PPM \& PLP. 2013.
3. DinKes Kalimantan Selatan. Laporan Tahunan Dinas Kesehatan Provinsi Kalimantan Selatan Tahun 2013. Banjarmasin: DinKes Provinsi Kal-Sel. 2013.

4. Puskesmas Pudi. Laporan Tahunan Puskesmas Pudi Kabupaten Kotabaru Tahun 2013. Kotabaru: Puskesmas Pudi. 2013.

5. Rosalina, Santi. Strategi Penanggulangan Infeksi Saluran Pernafasan Akut pada Anak Balita Melalui Analisis Faktor Determinan di Tiga Kecamatan Kabupaten Ogan Ilir Sumatera Selatan Tahun 2006. Tesis. Medan: Universitas Sumatera Utara. 2006.

6. Rumaolat, W., MSJ Malisngorar, Epi Dusra, Ulima Asni. The factors related to occurrence of ARI (Acute Respiratory Infection) on Pre-School children in woring area of Kairatu Public Health Center, Western Part of Seram Regency 2016. Dama International Journal of Researchers. 2016: Vol 1(11): 62-68,

7. Azad, Kazi Md. Abul Kalam. Risk factors for Acute Respiratory Infections (ARI) among children under five years in Bangladesh. Journal of Scientific Research. 2009: 1(1): 72-81.

8. Chalabi, DAK. Acute respiratory infection and malnutrition among 
children below five years of age in Erbil Governorate, Iraq. Eastern Mediterranian Health Journal. 2013: Vol. 19 No. 1.

9. Wahyuni, Ni Putu Sri. Pengaruh particulate matter $\left(P M_{10}\right)$ udara rumah tinggal terhadap infeksi saluran pernafasan akut (ISPA) pada balita di wilayah kerja Puskesmas Pejuang Kecamatan Medan Satria Kota Bekasi tahun 2013. Jakarta: FKM UI. 2013.

10. Farieda, Asma. Pengaruh particulate matter $\left(P M_{10}\right)$ dalam rumah terhadap ISPA pada balita (studi pada pemukiman sekitar kawasan industry di Kecamatan Ciwandan Kota Cilegon Provinsi Banten tahun 2009). Jakarta: FKM UI. 2009.

11. Umbul, C.W. Faktor Lingkungan dan Karakteristik Santri Terhadap Kejadian ISPA di Pondok Pesantren. Info Kesehatan 2004; VII (2); 97-102.

12. M.Nur, Hidayati. Faktor-Faktor yang Berhubungan dengan Kejadian Penyakit ISPA pada Balita di Kelurahan Pasie Nan Tigo Kecamatan Koto Tangah Kota Padang. Medan: Universitas Sumatera Utara. 2009.

13. Lubis, P. Perumahan Sehat. Proyek Pengembangan Tenaga Sanitasi Pusat. Depkes RI. Jakarta. 2005.
14. Taisir. Faktor-Faktor yang Berhubungan Dengan Kejadian ISPA pada Balita, di Kelurahan Lhok Bengkuang Kecamatan Tapak Tuan Aceh Selatan Tahun 2005. Medan: Skripsi FKM USU. 2005.

15. Prietsch, S.Q.M, Fischer, G.B, Cesar, J.A, et al. Acute lower respiratory illness in under-five children in Rio Genre, Rio Grande do Sul State, Brazil: Prevalence and risk factors. Cad. Saude Publica, Rio de Jeneiro. 2008: 24(6): 1429-1438.

16. Fakunle GA, Ana GR, Ayede Al. Environmental risk factors for acute respiratory infections in hospitalized children under 5 years of age in Ibadan, Nigeria. Paediatr Int Child Health. 2014: 34(2): 120-4.

17. Padmita AC, Wulandari RA. Exposure to environmental factors with acute respiratory infection (ARI) among children under five years at Hamlet 1 of Ciampea Village, Ciampea Sub District, Bogor District 2013. International Conference on Innovative Trends in Multidisciplinary Academic Research (ITMAR). 2014: Vol 1: 448-461. 